Currículo sem Fronteiras, v. 19, n. 3, p. 1094-1114, set./ dez. 2019

\title{
INFÂNCIA E CURRÍCULO: uma articulação inevitável e necessária
}

\author{
Luana dos Santos Nogueira Garcia \\ Universidade do Estado de Mato Grosso - UNEMAT \\ Maritza Maciel Castrillon Maldonado \\ Universidade do Estado de Mato Grosso - UNEMAT
}

\begin{abstract}
Resumo
Neste artigo, propomo-nos a problematizar alguns discursos filosóficos (principalmente os platônicos e iluministas) sobre a infância e a pensá-la a partir de outras brechas, isto é, perceber como o discurso filosófico platônico ainda encontra ressonâncias no currículo escolar, projetando corpos infantis ao futuro. Buscamos, ainda, apontar como os artefatos culturais contribuem para o alcance desse objetivo na escola e mostrar como as crianças furam o domínio do instituído e criam possibilidades outras, que tornam o currículo molar, vivo, flexível, rizomático, trazendo novos modos de ser e de estar na escola. Trata-se do resultado de uma pesquisa de campo realizada em uma escola pública estadual, recente e tradicional situada no município de Mirassol D’ Oeste, na mesorregião sudoeste do estado de Mato Grosso.
\end{abstract}

Palavras-chave: Escola. Currículo. Infâncias.

\begin{abstract}
In this paper, we aim to problematize some philosophical discourses about childhood (particularly the platonic and illuminist ones), and think about it in other ways, i.e. understand how the platonic philosophic discourse still has effects on the school curriculum by projecting children's bodies to the future. We also attempt to point out how cultural artifacts have contributed to attain this goal at school, and show how children have both disrupted the domain of the instituted and created other possibilities, which make the curriculum molar, living, flexible, rhizomatic, thus bringing up new modes of being at school. This paper has derived from a field research carried out in a recent, traditional state public school located in the city of Mirassol D' Oeste, in the south-west mesoregion of the state of Mato Grosso.
\end{abstract}

Keywords: School. Curriculum. Childhoods. 


\section{Introdução}

Dia 02 de maio de 2019, quinta-feira, aula de Ciências. Era uma manhã de sol... A aula já havia começado. Batemos na porta da sala, pedimos licença ao professor e entramos. Deparamos com a lousa cheia de escritas (fluxos do professorado) e com alguns alunos enfileirados, outros em duplas, e alunas sentadas no chão em frente à lousa. O tema da aula era muito curioso por sinal: Sistema Digestório. "Tantos órgãos e nomes diferentes", exclamou um aluno. Para não atrapalhar a aula, fomos logo para o fundo da sala (nosso lugar de experimentações e encontros). Logo vimos que mesas não haviam sobrado, então, pegamos as duas únicas carteiras que estavam ali à nossa espera. Como de praxe, pegamos o nosso caderno de campo e começamos a anotar os detalhes ínfimos daquela aula (estes que acabamos de contar), porém, como não havia mesa para escrever, nos apoiamos na mochila (o único artefato que tínhamos para isso). Escrita vai, pensamentos vêm... Quando, de repente, um aluno timidamente se aproximou e disse: "Peguem esta mesa, professoras. Com ela, fica melhor para as senhoras escreverem”. (Anotações cartográficas - um gesto de afeto).

O desafio de uma pesquisa ${ }^{1}$ é traduzir os seus efeitos a partir da escrita. Entre as perguntas e as respostas (se é que existem!), passam-se agenciamentos enumeráveis, acontecimentos incontroláveis e encontros inesperados. Estar no lócus de investigação (no caso, a escola) significa estar no fluxo das intensidades e das velocidades. Saber o que pode acontecer ali? Impossível! Esperar o que dos sujeitos (crianças) que ali habitam? O imprevisto, diríamos nós. No encontro com as crianças no/do cotidiano, (re)conhecemos a potência de sua existência. A criança é devir, é a multiplicidade temporal, “ela é o tempo intempestivo, o tempo de ruptura, a fratura, a descontinuidade daquilo que não sabemos, não somos, não está, estamos em via de nos diferir, e que será inventado” (ABRAMOWICZ, 2018, p. 375). Possuem singularidades, sorrisos e gestos... Tal qual aquele gesto citado na epígrafe deste artigo. Cá estávamos pensando... Como é bom experimentar a sensação de um gesto de afeto! Compreendemos afeto no sentido spinozeano, de o corpo afetar e ser afetado pelo mundo e pelo outro. Esse gesto nos afetou, nos atravessou, nos (des)fez, nos constituiu outras, diferentes de quem éramos alguns instantes antes de termos entrado naquela sala. Outras pessoas - talvez mais sensíveis diante dos acontecimentos e mais dispostas a escutar, a ver, a sentir.

Seria essa uma experiência que instiga o pesquisador a trilhar o restante do caminho de sua pesquisa? Talvez sim, talvez não. Não temos respostas. Porém, pensamos que os encontrospotentes $^{2}$ podem impulsionar ações, suscitar efeitos, criar vibrações. A partir da criança, pensando as vibrações, potências, intensidades que dela advêm, queremos aqui tentar abrir (des)caminhos para pensar o currículo e as singularidades da infância. Não queremos, com isso, apresentar um modelo curricular para um tipo de escola, nem trazer mais discursos sobre o que, de fato, seja a infância. Propomo-nos a problematizar os discursos filosóficos (principalmente os platônicos e iluministas) sobre a infância e a pensá-la a partir de outras brechas, isto é, perceber como o discurso filosófico platônico ainda encontra ressonâncias no 
currículo escolar, projetando corpos infantis ao futuro. Buscamos, ainda, apontar como os artefatos culturais contribuem para o alcance desse objetivo na escola e mostrar como as crianças furam o domínio do instituído e criam possibilidades outras, que tornam o currículo molar, vivo, flexível, rizomático, trazendo novos modos de ser e de estar na escola. Fazendo isso, pensamos estar seguindo uma marca deixada por Deleuze ao trabalhar com o conceito de perceptos - bem, realizaremos um exercício de compor novas maneiras de ver e escutar o currículo e as infâncias.

\section{Currículo, poder e produção de identidades}

Tudo parado. O dia acabou de começar. Eis que, por volta das 6 horas e 30 minutos, começam a chegar alguns alunos. Uns vêm a pé, por morarem perto da escola; alguns vêm sozinhos de bicicleta e outros vêm de moto ou carro com seus responsáveis. Os minutos vão passando... Gradualmente, os professores chegam à escola e vão para a sala dos professores; lá dialogam com seus pares à espera do sino das 7 horas. Pouco a pouco, a sala dos professores, que até então estava vazia e silenciosa, vai enchendo e se tornando um espaço de conversações. Os alunos, lá fora, percorrem o pátio. O silêncio que antes reinava naquele espaço fora substituído pelas vozes e ruídos daqueles que ali habitam. O sino toca. Os alunos vão para a sala de aula, assim como os professores. Lá se organizam em filas, duplas ou em círculo. Cadernos e lápis sobre a mesa. Professor à frente anuncia o conteúdo. A aula inicia... É assim que a Escola Machado de Assis $^{3}$ se movimenta todos os dias.

Olhar de fora o movimento cotidiano dessa escola torna-nos estrangeiras e estranhas. Visualizar os mínimos detalhes na condição de pesquisadoras fez-nos interpretar as relações espaçotemporais da escola de forma distinta; fez-nos pensar sobre aquilo que esquecemos diariamente, mas que caracteriza e impulsiona todas essas relações: o currículo. Fala-se tanto em currículo escolar nos cursos de licenciaturas, nas escolas e reuniões de pais e professores. Mas o que vem a ser o currículo? Ou melhor: que teorias existem sobre o que seja um currículo? Fazer esse questionamento possibilita apontar sobre qual perspectiva desenvolveremos nossas narrativas. Utilizaremos os estudos de Silva (2007; 2001; 1998) e Veiga-Neto (1995) para mover nosso pensamento e suscitar novas linhas de convergência nesse emaranhado de ideias.

O modo de conceber o currículo modifica-se de acordo com o período histórico que vivenciamos. Tudo é relação. Depende do contexto, do espaçotempo, dos saberes, das pessoas. De acordo com Silva (2007), o currículo é resultado de uma seleção de conhecimentos e saberes existentes em um determinado tempo. É nesse contexto que se encontram as "teorias do currículo", que servem para justificar "por que 'esses conhecimentos’ e não ‘aqueles’ devem ser selecionados” (SILVA, 2007, p. 15). Têm-se, nesse sentido, as teorias curriculares apresentadas por Silva (2007), que versam sobre as diferentes perspectivas do currículo no contexto educacional. Antes, é preciso a compreensão de que são teorias construídas histórica e culturalmente, então, conservam princípios, relações de saber e poder, concepções de sociedade, posições de sujeitos e princípios 
ideológicos e sociológicos distintos. Cada uma, à sua maneira, constituiu o currículo em consonância com a ordem discursiva da época.

Silva (2007) distingue as teorias curriculares em: teorias tradicionais, críticas e póscríticas. Cada uma dessas perspectivas enfatiza um determinado conhecimento, que constituirá aquilo que chamam de currículo. A primeira detém uma concepção conservadora do currículo, na qual o ensino se resume a desenvolver determinadas habilidades, restringindo-se “à atividade técnica de como fazer o currículo” (SILVA, 2007, p. 30), isto é, pauta-se em uma questão meramente técnica e instrumental. Concentra-se em um ensino humanístico, autoritário, transferível, mecânico e centrado no professor. O que conta são apenas os resultados, e não o processo da aprendizagem.

As teorias críticas do currículo contrapõem-se às teorias tradicionais dominantes e colocam-nas em xeque; emergem buscando transformações radicais para compreender o que o currículo faz. Há, nesse sentido, a valorização dos conteúdos curriculares universais, da relação interativa professor-aluno e da avaliação escolar como meio para realizar novas práticas e intervenções pedagógicas. Isso se contrapõe à razão iluminista, ao ensino técnico e aos conhecimentos dominantes da sociedade. O currículo passa a refletir a função social da escola, valorizando os conteúdos produzidos durante a história da humanidade e assumindo novos ideais, os quais vão compor o pensamento da sociedade da época.

Com a pós-modernidade, constituem-se as teorias pós-críticas do currículo, trazendo questões que até então não se constituíam em saberes a serem discutidos na escola. Essas teorias possuem um modo de pensar distinto e englobam novos modos epistemológicos e filosóficos de pensar o currículo. Colocam em questão as verdades absolutas e o pensamento linear, estático, engessado e imutável; partem da ideia de que os significados são produzidos socialmente mediante relações de poder. O currículo, então, é uma prática de significação e de representação, uma vez que concebe a realidade a partir dos discursos que dizem sobre como ela deveria ser. Identidade, alteridade, subjetividade e diferença são questões constantemente problematizadas nessa perspectiva, perpassadas por relações de saber $e$ poder, tal como o currículo.

Nessa linha de pensamento, Silva (2007, p. 16) questiona: “quais interesses fazem com que esse conhecimento e não outro esteja no currículo? Por que privilegiar um determinado tipo de identidade ou subjetividade e não outro?”. Partindo dessas perguntas, necessário se faz retomar algo essencial para pensar o currículo: o poder - aquilo que diferencia a teoria pós-crítica das demais. Pretendemos problematizar o currículo a partir da teoria pós-crítica por acreditar que ele seja um produtor de identidades e agenciado por relações de poder.

Para Veiga-Neto (1995, p. 50), o currículo "pode ser compreendido como um dos poderosos dispositivos pelos quais a escola procede à objetivação e subjetivação”. É isso que o currículo faz: "produz um modo de existência” (DELEUZE, 1992, p. 123). Nas escolas, quando privilegiamos determinados saberes a ensinar, e não outros, estamos subjetivando, estamos produzindo determinados tipos de sujeitos, que poderiam ser constituídos de outra forma. Nossas escolhas produzem os alunos que temos, por isso, partilhamos as ideias de Silva (2001) quando pontua que o currículo produz identidades, estabelece diferenças e demarca hierarquias. Logo, currículo é também uma questão de poder! 
Foucault (1979) diz que o poder é uma prática social que está em todo lugar; não está em sujeitos, mas nas relações sociais existentes entre eles. "Por isso ele é dito microfísico. Ele é força, e relação de força, não forma” (DELEUZE, 1992, p. 112). O currículo, pensado enquanto uma questão de poder, nos faz questionar as relações de força presentes nas escolas no processo de constituição de identidades. Questionamos: quais relações de força estão imbricadas nas escolhas dos artefatos tecnológicos usados na escola? Que identidades infantis constituímos quando privilegiamos determinado conhecimento escolar ou determinado artefato cultural tecnológico?

Masschelein e Simons (2018), analisando as acusações e demandas feitas à escola, dizem que alguns críticos concebem a rendição desta ao capital como não acidental. Nessa perspectiva, o currículo torna-se "um meio ou um instrumento para perpetuar o poder" (MASSCHELEIN; SIMONS, 2018, p. 15). Isso significa que "o currículo produz, o currículo nos produz" (SILVA, 2001, p. 27). Produz as crianças que estão nas escolas, produz os professores e toda a comunidade escolar. Somos subjetivados a todo instante, logo, "nos tornamos seres intensamente subjetivos” (SILVA, 1998, p.33).

Essa problemática leva-nos a pensar nas redes de subjetivação que nos capturam todos os dias e produzem as nossas identidades. Não tem para onde fugir! As identidades, sejam elas infantis ou de adultos, são construídas pelo currículo e por outras redes. Resta-nos, enquanto professores, fazer nossa aposta e escolher uma perspectiva de currículo que seja coerente com aquilo que acreditamos.

Qual nossa aposta, qual é o nosso lado nesse jogo? O que vamos produzir no currículo, entendido como prática cultural? Os significados e sentidos, as representações que os grupos dominantes fazem de si e dos outros, as identidades hegemônicas? Vamos fazer do currículo um campo fechado, impermeável à produção de significados e de identidades alternativas? Será nosso papel o de conter a produtividade das práticas de significação que formam o currículo? Ou vamos fazer do currículo um campo aberto que ele é, um campo de disseminação de sentido, um campo de polissemia, de produção de identidades voltados para o questionamento e a crítica? Evidentemente, a resposta é uma decisão moral, ética, política de cada um/uma de nós. Temos de saber, entretanto, que o resultado do jogo depende da decisão de tomarmos partido. O currículo é, sempre e desde já, um empreendimento ético, um empreendimento político. Não há como evitá-lo (SILVA, 2001, p. 29).

Pensar dessa forma permite-nos ter em mente as múltiplas possibilidades de linhas de fuga existentes. Podemos contribuir para a construção de identidades outras que fujam dos binarismos, das verdades absolutas, das hierarquizações e dos propósitos doutrinários. Fazer do currículo um espaço de experiências, de encontros e composições é concebê-lo como "lugar, espaço, território" (SILVA, 2007, p. 150).

Currículo não é uma relação particular, não é isso OU aquilo. Currículo não é um programa de ensino OU o conjunto de matérias escolares. Currículo não é oculto OU real. Currículo não é o campo de ações OU grade curricular. Não, nada disso. O que conta para 
Deleuze (1992) é o E , a conjunção E. “O E é diversidade, a multiplicidade, a destruição das identidades” (DELEUZE, 1992, p. 60). Quando instauramos a lógica do E, não privilegiamos nem um, nem outro - é sempre o entre, as fronteiras, os fluxos.

O currículo, desse modo, é relação de poder, $\mathbf{E}$ percurso, $\mathbf{E}$ viagem, $\mathbf{E}$ discurso, $\mathbf{E}$ documento, $\mathbf{E}$ agenciamentos, $\mathbf{E}$ encontros, $\mathbf{E}$ composições, $\mathbf{E}$ saberes, $\mathbf{E}$ identidades, $\mathbf{E}$ diferenças, $\mathbf{E}$ subjetividades, $\mathbf{E}$ imanência, $\mathbf{E} . . . \mathbf{E}$... $\mathbf{E}$... A lógica do $\mathbf{E}$ cria novas direções e fronteiras, faz visível o imperceptível, pois, é nas fronteiras, nos espaços entre que as coisas se passam...

\section{Que currículo para que escola?}

Valendo-nos do questionamento proposto por Candau (2008) no título desta seção, queremos problematizar o currículo enquanto sistema rizomático (DELEUZE; GUATTARI, 1995) que possui formas diversas, não fixado a uma ordem ou a um pensamento arborescente, mas que pode fazer conexões a qualquer ponto, pode produzir linhas de fuga e desterritorializações. Quando fazemos esse questionamento, queremos apontar que o currículo é múltiplo e, sendo múltiplo, pode ser estratificado, territorializado, agenciado. Não existe um currículo para determinada escola, assim como não existe um rizoma justificado por modelos estruturais (DELEUZE; GUATTARI, 1995). Isso significa que o rizoma, da mesma maneira que o currículo, pode ter suas linhas rompidas, porém, estabelece novas linhas em outras direções; é reversível e pode receber modificações constantemente.

Seguindo linhas múltiplas, o rizoma é impedido de voltar “ao mesmo”. Ele não é decalque. É possibilidade. É criação. Pensamos que o currículo não pode ser concebido como decalque, mas como multiplicidade, como rizoma, com suas linhas de fuga que permitem “explodir os estratos, romper as raízes e operar novas conexões” (DELEUZE; GUATTARI, 1995, p. 24). É isso! É o agir nas brechas. É a produção de multiplicidades que fazem emergir possibilidades, as quais escapam a qualquer controle, a qualquer hierarquia ou linearidade.

Essa busca por estabelecer uma proximidade com aquilo que concebemos como currículo lembrou-nos do texto em torno de uma educação menor, de Silvio Gallo. Na medida em que concebemos o currículo como ato de resistência e vontade de potência, potencializamos os sentidos e fazemos proliferar os significados (LEAL, 2011) dados a ele. Falar de brechas e fissuras no currículo é falar de um currículo menor, que se opõe aos fluxos instituídos, que resiste às políticas da educação maior, impostas, e produz diferenças. É falar de um currículo sem receitas prontas, sem modelos, caminhos ou soluções; é falar de uma "aposta nas multiplicidades, que rizomaticamente se conectam e interconectam, gerando novas multiplicidades” (GALLO, 2002, p. 176); é falar em resistência, em persistência e em ato de potência!

Essas questões sobre escapes, linhas de fuga e ato de potência remetem-nos a uma conversa travada durante nossa pesquisa na Escola Machado de Assis com um praticantepensante que leciona no $5^{\circ}$ ano do ensino fundamental. Ao questioná-lo sobre o uso dos artefatos tecnológicos em sala de aula, ele apresentou, em sua fala, possibilidades de 
escapes às regras da escola, ao currículo instituído, às verdades impostas e ao pensamento arborescente dominante:

Há poucos dias, estávamos desenvolvendo um projeto na disciplina de artes e estávamos trabalhando os tipos de artes. Conforme o combinado, deixamos de fora apenas a dança e o teatro, porque eles serão trabalhados mais aprofundados adiante, até por apresentações na própria escola. E aí, numa ocasião, eu liberei um grupo que estava responsável por apresentar o tema "fotografia", o tipo de arte "fotografia", que é um tipo de arte moderna. Entreguei meu celular para eles, e eles foram ao pátio fazer as fotografias. Então, assim, isso engrandece demais. Primeiro, engrandece a questão da confiança: "olha, o professor está me dando o celular dele para eu fotografar". Segundo, eles estão utilizando, eles estão fazendo, eles fotografando. Então, o trabalho depois foi pegar essas fotos que eles fizeram no pátio (de árvores, de flores), passar para o PowerPoint e fazer a apresentação no slide. Você precisa ver o sentimento deles ao verem aquele trabalho que eles criaram, que eles fizeram. Outro grupo, que apresentou literatura, já trouxe os slides deles prontos. Então, você vê que eles já têm noção, já montaram o slide em PowerPoint em casa e trouxeram pronto. Teve quem trouxe escultura, uma miniescultura de um curral para mim. Muito bacana! Você vê que alguém acabou ajudando e tal, mas fez. Então, isso é muito enriquecedor. Isso deixa a gente... É aquele tipo de coisa em que o professor vai embora pisando em nuvens, sabe? (Professor Enzo ${ }^{4}$ ).

Esse depoimento foi potente! Principalmente quando o professor apontou, após a entrevista, que entregou bilhetes autorizando o uso do celular por aqueles alunos que foram ao pátio fazer fotografias e vivenciar esse tipo de arte moderna. Então, se alguém da gestão escolar aparecesse e visse grupos de alunos fora do horário de aula e, como se não bastasse, com um celular na mão, percorrendo o pátio da escola, haveria a possibilidade de justificar o uso de tal artefato. Olha que interessante! O uso do celular pelos alunos é negado na escola, mas o professor - com toda a sua autoridade e poder - consegue burlar as regras e propiciar o contato com esse artefato e seu uso pelos alunos.

Essa situação evidencia aquilo que Larrosa (2018) chama de ofício de professor. O ato de entregar um celular na mão de uma criança e deixá-la livre para realizar o trabalho escolar significa uma abertura. Abertura para o mundo, para a aprendizagem, para o devir. $\mathrm{O}$ professor, nesse sentido, despertou o interesse dos alunos, abriu mundos e ofereceu possibilidades de encontros. Com o quê? Ah... "Com outros espaços de liberdade do lado fora” (LARROSA, 2018, p. 242). Pensando sobre isso, acreditamos que "entre ensinar e aprender pode haver muito mais do que aquilo que as técnicas de ensino, os recursos didáticos, os livros especializados e os conteúdos assimilados pretendem realizar” (LEAL, 2011, p. 48). Pode haver o novo, o imprevisto, o extemporâneo. Isso é abrir mundos!

O professor não busca resultados, mas provoca efeitos. O professor não mede a passagem do tempo, mas “tem que 'fazer tempo' (um tempo lento, orientado, des-sincronizado, não mercantilizado) e 'dar tempo”” (LARROSA, 2018, p. 320). Isso significa a fuga do Chrónos, 
do tempo que nos devora, do tempo cronometrado, das aulas aceleradas. Sendo assim, questionamos: há espaço para esse tempo de intensidade, de sentidos, no currículo escolar? Pensamos que sim. Contudo, é preciso das mãos e das maneiras hábeis, pacientes, felizes e cuidadosas (LARROSA, 2018) daqueles que estão na escola para "convocar, mostrar, assinalar, ensinar, chamar a atenção, convidar (para a conversação, o exercício e o estudo), disciplinar, interessar e coisas assim” (LARROSA, 2018, p. 114).

Isso quer dizer que é preciso colocar em questão, inclusive no currículo, aquilo que já se sabe sobre ensinar e aprender, ou melhor, sobre o aprenderensinar ${ }^{5}$. Para Leal (2011), nem tudo que ensinamos alguém aprende. Por isso, o ofício do professor não se reduz ao ensino. É muito mais do que isso. É abrir mundos, suscitar encontros. É oferecer os signos. A aprendizagem é o lugar onde se oferecem signos. Como diz Larrosa (2018), aprender diz respeito, essencialmente, aos signos; aprender é decifrar ou interpretar os signos de uma matéria, objeto ou ser. Nesse sentido, todo ato de aprendizagem é uma interpretação de signos. Os signos estão por toda parte! O mundo oferece signos que precisam ser decifrados. Cabe ao professor, contudo, oferecer novos signos para que a criança aprenda, isto é, "chamar os novos para o mundo, para essa parte do mundo que é sua matéria de estudo, fazer com que sejam sensíveis aos signos que emite” (LARROSA, 2018, p. 273).

Porém, nem todos os signos serão interpretados pelos alunos, porque a aprendizagem é múltipla e acontece de diferentes formas. O acontecimento acontece para cada um de uma forma distinta (DELEUZE, 1992). Então, no ato do professor de lançar signos para os alunos, nem todos vão aprender da mesma forma, mas cada um à sua maneira, no seu tempo, com o seu processo próprio de aprendizagem. Nessa conjuntura, questionamos: quais são os signos que o professor está oferecendo para que a criança aprenda? Como ele está oferecendo esses signos? Como esse novo mundo está sendo apresentado para a criança? O professor está apresentando, mediante o uso de artefatos tecnológicos, novos signos aos alunos?

Esses questionamentos fizeram-nos tecer significações/sentidos sobre a narrativa de uma das professoras entrevistadas:

Cartolina, a gente produz bastante, até estou trabalhando com eles, fazendo um Ebook Cultural, utilizando a cartolina no formato de um livro, mas como se fosse essa ferramenta digital que a gente cria. Essa intenção partiu da curiosidade deles, porque eu trago o meu notebook, às vezes, mas o tablet, ele é mais portátil. Então, eu trago até por questão também de a ferramenta ser menor e tudo mais, para eles pesquisarem, e aí surgiu dessa curiosidade, desse interesse deles. Então, eu dei uma pausa agora porque a gente começou a semana de provas, mas eu estou trabalhando, dentro de história, a questão dos fatos históricos e os documentos históricos, a partir do conteúdo que nós utilizamos, estudamos dentro do livro didático. Aí, passei para eles, para eles verem as imagens que eu pesquiso, para eles pesquisarem também. E cada um, cada grupinho está com um tema, se é documento histórico, oral ou não oral, os fatos históricos daquela cidade, de quando eles nasceram. Então, a gente vai montar esse e-book e aí dentro, se possível, a gente conseguir esse recurso das imagens para colocar, eles fazerem como se fosse uma linha do tempo, uma régua do tempo, mas foi um 
pouco voltado para a sala, assim, que não é uma ferramenta digital em si, mas é como se fosse. Simular aquela sensação, criar essa sensação (Professora Laura).

Olha que interessante... Quais foram os signos oferecidos por essa professora aos seus alunos? Essa tática de criar um E-book Cultural a partir de uma cartolina, objetivando simular o uso de uma ferramenta digital, é um ato criativo que dá voz à experiência (LARROSA, 2017). À experiência de quem? Dos alunos. Da professora. De todos os corpos que experienciam esse processo de criação. A sensação que a professora busca provocar nos alunos é “a sensação de que pode experimentar livremente com sua matéria o próprio ato de apresentá-la às novas gerações” (LARROSA, 2018, p. 50). É a sensação do aprender e deixar aprender (KOHAN, 2004). É propiciar os sentidos e o uso de um artefato que muitos alunos não podem ter. Esse talvez seja o essencial do ato pedagógico: oferecer signos, promover possibilidades e propiciar encontros. Nesse caso, vemos a professora como desenhista do processo de aprenderensinar; ela “desenha tempos (durações, séries, ritmos), espaços (posições, disposições, composições de corpos e materialidades) e atividades (procedimentos, modos de fazer, exercícios, tarefas)” (LARROSA, 2018, p. 173).

Trata-se de invenções que movimentam o cotidiano escolar. Para Oliveira (2010), são ações criadas pelos praticantespensantes para jogar com as possibilidades passíveis de exploração. As ações criadas pela professora entrevistada movimentaram "o cotidiano, com as suas maneiras próprias de usar os produtos culturais oferecidos no mercado dos bens" (OLIVEIRA, 2010, p. 127), isto é, as formas de fazer uso criativo de um artefato cultural que a ela foi disponibilizado. Pensamos que o cotidiano e a aprendizagem precisam ser renovadores para chamar a atenção dos alunos, para despertar o “desejo de saber” (KOHAN, 2015, p. 88). Contudo, nem sempre, com a vida corrida do dia a dia, com os problemas pessoais, com as preocupações que nos afligem, conseguimos ser renovadores, ou mesmo criadores, inventores.

A vida de professor exige de nós muito empenho e "esforço de pensamento criativo" (ALVES; GARCIA, 2000b, p. 35), por isso, ser um professor oferecedor de signos, de possibilidades, de encontros, talvez nos tire um pouco o peso do ensinar-aprender. É preciso apenas a oportunidade para que os acontecimentos possam surgir e movimentar o cotidiano. Uma simples ida ao pátio da escola, a leitura de um livro, uma roda de conversa, podem propiciar acontecimentos singulares na vida dos alunos. Basta tornarmo-nos sensíveis aos signos que queremos emitir.

Então... Que currículo para que escola?

Bem... Com inspiração nos autores anteriormente citados, pensamos que as escolas são múltiplas, assim como os profissionais que nela trabalham. Será que existe ou poderá existir um currículo que atenda aos anseios e desejos de cada um e que se encaixe em sua forma de pensar? "Como criar para si um Currículo-Clandestino que desenvolva, no campo curricular, um novo espaço de pensar?” (CORAZZA, 2012, p. 13). Há possibilidades de se criar um currículo ideal para tudo e todos? E... Queremos um currículo ideal? Talvez não.

Mas desejamos currículos plurais que, ao menos, atendam aos conhecimentos plurais do mundo; que abarquem o outro que é profano, desviante, o negativo, de fora, estrangeiro, e 
que por isso é silenciado, negado, indocumentado, obscurecido e anormalizado; que desconstruam padrões de normalidade - principalmente aquele estabelecido pelo pensamento ocidental, que positiva o homem branco, heterossexual, adulto, machista, racional e burguês - que estereotipa, silencia e legitima as diferenças; que atendam à diversidade, sobretudo, as minorias. Currículos que, inclusive, percebam "as crianças como cidadãs de agora, com as suas especificidades, mas como cidadã de agora, que pensa, que cria” (Professor Enzo) e que vive em um mundo contemporâneo permeado por possibilidades, por artefatos inexistentes até poucas décadas atrás. Sobre isso, em uma conversa com outra professora, ela assinalou o seguinte: "o nosso olhar das crianças de décadas atrás era algo mais, de certa forma, limitado, e eu também até ouso falar um pouquinho que as crianças ficavam limitadas àquilo ali. Hoje, não! Hoje, eu acho que eles já vão em busca, pesquisar e saber" (Professora Laura). Embora relativizemos um pouco sua fala, é nesse sentido que dizemos que o currículo é e precisa ser múltiplo, para que possa atender a todas essas novas demandas advindas com a contemporaneidade, advindas com a criança contemporânea, que deseja falar e ser ouvida, que é a protagonista do processo de aprenderensinar.

\section{Um currículo-desejante em trânsito, movente e molecular}

As pesquisadoras, do fundo, observavam. Era aula de Educação Física. Crianças no pátio e na quadra de areia brincavam. Se fosse possível ser invisível naquele momento, seríamos. Ninguém notava nossa presença ali (ao menos, era o que parecia). Gritos, risos, conversas, acordos e discussões entre as crianças misturavam-se com o canto das araras MaracanãGuaçu, que davam uma beleza singular àquele lugar.

Eis que uma cena capturou nossos sentidos! De um lado do pátio, um grupo de meninos jogava vôlei, e outros brincavam de pingue-pongue; do outro lado, um grupo de meninas pulava cordas, e outras brincavam de pingue-pongue. Os pensares sobre as relações de gênero na escola vieram à tona. Confessamos que ficamos incomodadas diante daquela situação. Questionamos sobre a função do professor naquele momento. Intervir e acabar com a divisão que separava as meninas dos meninos? Ou abster-se? Ficamos sem reação, sem respostas.

O professor da turma, diante do efêmero e do imprevisível, deixou o modo organizativo elaborado pelos próprios alunos prevalecer. Transitou de grupo em grupo, sanou as dúvidas, contribuiu no desenvolvimento das atividades e até ousou participar das brincadeiras. Fez aquilo de oferecer signos e deixar que os alunos os interpretassem. Naquele momento, como diria Larrosa (2017), fomos picadas. Afetamo-nos naquele campo extemporâneo. Os esforços que fizemos para perceber as sutilezas daquilo que estava no intermezzo, nos interstícios daquela cena, potencializaram-nos para ver o imperceptível, para criar novos mundos possíveis e abandonar as certezas e verdades absolutas.

Subitamente... Surpreendemo-nos novamente! Quando menos esperávamos, os grupos desfizeram-se. Meninas foram jogar vôlei, meninos entraram na fila de pular cordas, e os grupos de meninos e de meninas que brincavam de pingue-pongue separadamente juntaramse. Os fluxos e movimentos que existem nos cotidianos das escolas impressionam-nos. É 
interessante o movimento que existe ali. São zonas de intensidade. Nada é estático, tudo é fluxo - “atravessado por delicadas passagens, dolorosos conflitos, fascinantes descobertas” (LEAL, 2011, p. 82). Esse episódio provocou a escuta atenta aos imperceptíveis desenrolamentos a que o cotidiano pode levar-nos. Nesses momentos inesperados,

é necessário começar tudo de novo, mergulhar em cada cena, de modo que você (seu corpo vibrátil): possa captar não mais os planos e sim os platôs, as regiões de intensidade contínua, feitas da latitude dos corpos que você for encontrando: corpos humanos, animais, sonoros... Corpos de uma ideia, de uma língua, de uma coletividade (ROLNIK, 2016, p. 39, grifo da autora).

Algo se passa nesse movimento de encontros e intensidades. São fluxos que insistem em escorrer. Para Kohan (2010, p. 117), “as crianças vazam na escola outros fluxos. A questão é que nem sempre estamos preparados para ver, para compreender as crianças como sujeitos de poder, não atentando para suas ações”. Essa fluidez, inclusive aquelas pensadas por Bauman (2001), produz forças inventivas nas escolas, vislumbrando-se modos outros de composições entre os corpos, constituindo-se significações que passam pelo campo do sensível.

Destacamos aqui uma passagem que atravessou nossos pensamentos sobre as experiências do professorado, suas derivas, tentativas e fluxos.

Dia 16 de abril de 2019, 08h30min, aula de Português. Alunos enfileirados com os livros abertos na página de um texto intitulado "a casa mal assombrada". Olhares curiosos percorrendo a história. De repente, o professor foi até o armário localizado no fundo da sala. Naquele lugar, pegou uma lata e a deixou sobre a mesa. Revestida por papel contact e tampada com apenas um pequeno furo ao meio, a lata chamava a atenção; desperta curiosidades para aqueles que a veem pela primeira vez e não têm uma representação sobre o seu significado. Eis que o professor fala: “- a caixinha do desabafo está ativa!”. Significados começaram a fluir (Anotações cartográficas - o cotidiano pulsa).

A cena passa-se em uma sala do $5^{\circ}$ ano do ensino fundamental. Esse é um exercício de escuta e experimentação. Os fluídos desses movimentos encontram-se em um continuum de intensidades. A experiência exige certa sensibilidade. Então... Na tentativa de entender o que se passava, esperamos a hora do lanche para perguntar ao professor. Após a conversa, descobrimos que era uma "caixa” criada pelo professor, destinada aos alunos que tinham alguma angústia, confissão, desabafo a fazer ou mesmo uma sugestão, uma alegria, um acontecimento que gostaria de compartilhar. Foi criada porque o professor, com seu olhar sensível, buscava encontrar alguma possibilidade de aproximar-se dos seus alunos, seus anseios e desejos. O professor, segundo Larrosa (2018), junto ao seu amor pela matéria, também ensina por amor aos alunos e, assim, preocupa-se e envolve-se ativamente. Sua dedicação é revelada a partir de pequenos atos e gestos, que se expressam pelo seu envolvimento em seu ofício. Dessas invenções cotidianas, surgem as fissuras, as quais o 
professor, nesse caso, transformou em momentos únicos de experimentação que possibilitam escutas imprevisíveis e situações inesperadas.

No universo dos cotidianos escolares, encontramos ações inventivas que irrompem nos currículos vazios - aqueles que retiram dos alunos/as a oportunidade de aprender o que neles não está incluído (ALVES; GARCIA, 2000a) -, incitando os fluxos curriculares a convergirem para uma realidade inventiva, potente e errante.

Queremos transitar, a partir dessa experiência, em um universo de múltiplos reveses, de descontinuidades, para compor novas tessituras sobre o currículo. Compreendemos que a ideia de um currículo que apresente vazamentos que desviem, que escapem de um modelo estrutural ou de um sistema (DELEUZE; GUATTARI, 1995), seja um bom caminho para começar. Deleuze e Guattari (1995) são autores que não apresentam conceitos voltados especificamente para escola, criança e currículo, contudo, seus textos e ideias contribuem para que possamos tecer relações entre tais temáticas. O que estamos fazendo aqui, portanto, é uma tentativa de relacionar o currículo com o pensamento desses filósofos.

Quando dizemos que o currículo apresenta vazamentos, estamos nos referindo aos escapes, às linhas de fuga existentes nos campos curriculares, sendo possível burlar os sistemas arborescentes segmentados. Isso possibilita questionar os modelos dominantes e os currículos capturados por tais estruturas engessadas. O currículo é, de fato, agenciado. Se não for pelo sistema imposto, é por outras linhas de segmentaridade.

A ideia de vazamentos proposta por Deleuze e Guattari (1995) leva-nos a pensar nas "linhas de visibilidade, de enunciação, linhas de força, de subjetivação e de ruptura" (ABRAMOWICZ, 2017, p. 137) que compõem o dispositivo currículo. São linhas que não "abarcam nem delimitam sistemas homogêneos por sua própria conta (o objeto, o sujeito, a linguagem), mas seguem direções diferentes, formam processos sempre em desequilíbrio, e essas linhas tanto se aproximam como se afastam uma das outras” (DELEUZE, 1990, p. 155). Elas se cruzam, se entrecruzam, resultando na pluralidade de possibilidades singulares que tendem a se (re)produzir no plano da organização curricular.

Dessa forma, parece propícia a tentativa de pensar o currículo como uma linha de fissura - que se abre, rompe, fratura - criando transbordamentos e novas conexões; ou ainda, como um dispositivo molecular, como nos propõe Deleuze ao problematizar as relações macro e micro existentes na sociedade. Deleuze, no livro intitulado O Anti-Édipo, diz que toda sociedade, mas também todo indivíduo, são atravessados por um modelo molar - macro, arbóreo, binário, segmentar - ou por um modelo molecular - micro, microscópico, rizomático, nômade. Segundo Guattari e Rolnik (1996, p. 321), “a ordem molar corresponde às estratificações que delimitam objetos, sujeitos, representações e seus sistemas de referência. A ordem molecular, ao contrário, é a dos fluxos, dos devires, das transições de fases, das intensidades”. Enquanto a primeira apresenta uma linha de segmentaridade dura, estática, arborescente, a segunda movimenta-se através de linhas de segmentaridades flexíveis, intensas, transitórias e em constante devir.

O currículo pensado enquanto linha molar formata, homogeneíza, padroniza. Atravessa todo o corpo escolar, sobrecodificando os agenciamentos em compartimentos, produzindo classificações, dividindo as identidades e particularidades. Está subordinado ao sistema 
dominante que opera poderes diversos e, assim, funciona por reprodução. Apresenta maior rigidez em suas práticas discursivas e não discursivas e traça planos definidos que estão no mundo das ideias, no mundo inteligível, transcendental - fora do espaçotempo, da imanência. O currículo enquanto linha molecular, por sua vez, é imanente, penetra nas singularidades, desfaz as codificações e sobrecodificações, produz linhas de fuga desejantes, cria movimentos, fluxos e afetos. Tal afirmação implica pensar em um currículo sem modelos, sem estruturas dominantes arbóreas, onde não é conduzido ao Uno (n), mas ao n-1, que se move, se mistura e cria novas direções. Nele, temos intensidade, linhas flexíveis que ressoam nos corpos, nas subjetividades, e que se abrem para campos de multiplicidades.

Esse movimento instaura uma abertura para um currículo-desejante que atua no campo molecular promovendo desvios, rompendo fronteiras, agenciando novas possibilidades de encontros. Se essa função fosse atribuída ao currículo, emergiriam novos modos distintos de pensar a escola e os elementos que a compõem; quiçá, percorrer terras desconhecidas, abrirse ao desconhecido, ao imprevisto, pode desconstruir as amarras atribuídas ao currículo este dispositivo disciplinar, de saber e poder, que captura os corpos infantis e os subjetiva diariamente.

\section{Os fluxos do devir-criança no contexto curricular e educacional}

Chegar à infância. Ela aparece última, no fim, à espera. A ela, quem sabe, podemos chegar. E para chegar a qualquer lugar há que se caminhar, buscar, sair de onde se está; há que se mexer, se desprender de algo que fixa a um lugar para poder ir ao encontro de outros lugares. Chegar à infância é, assim, um convite, um desejo, uma tentativa. Um caminho. (LEAL, 2011, p. 8).

Ao trazermos essa epígrafe, queremos demonstrar que chegar à infância é um percurso cheio de experiências, devires, composições; é a busca pelo desconhecido, pelo enigma que muitos tentam nomear. Não buscamos, com isso, apontar discursos legitimados e autorizados sobre o que ela é, mas problematizá-la, desconstruir verdades instituídas sobre a infância. Pensá-la no plural. Sendo a infância que habita a escola toda essa multiplicidade, como comprimi-la em um currículo denso, pesado, cercado, fixo? O currículo, para habitá-la, precisa ser híbrido, molecular, rizomático. Mesmo não sendo, ela sempre escapa! Sobre isso, lembramo-nos de um episódio que aconteceu durante nossos encontros com o cotidiano...

Dia 03 de maio de 2019, sexta-feira, aula de Ensino Religioso. Cadeiras organizadas em círculo para o início das apresentações sobre uma pesquisa encaminhada para casa. Quais são os rituais e costumes religiosos existentes em nossa sociedade? Esta foi a pergunta que movimentou a pesquisa dos alunos. Fonte de pesquisa? Aquela que pudessem ter acesso (pais, familiares, responsáveis, livros, internet). Os alunos estavam ansiosos para compartilhar o que descobriram. Conversas paralelas sobre as diferenças entre as pesquisas de cada um surgiram. Até que... O momento de apresentação começou! Professor 
foi à frente, chamou a atenção dos alunos e questionou: "Qual é mesmo a regra na sala de aula durante apresentações"? "Sem conversar e prestar atenção", responderam alguns alunos concomitantemente. De repente... A sala em silêncio ficou. Um aluno foi à frente, e sua fala iniciou... (Anotações cartográficas - os fluxos da disciplinarização).

Que cena! Os significados e sentidos sobre ela em nós brotavam e se entrecruzavam. O que pensar dos processos de disciplinarização que existem nas salas de aula? É isso que fazemos quando queremos o silêncio, a organização, o controle - para manter a ordem, a beleza e a limpeza. As infâncias são, assim, capturadas pelas escolas, pelas famílias e por outras instituições que têm como alvo o controle dos seus corpos e mentes. Contudo, essa atenção dada à infância nem sempre existiu. Ao reportarmo-nos à Antiguidade, por exemplo, percebemos que pouco interesse se manifestava pela infância, inclusive, Platão ${ }^{6}$ foi um dos primeiros filósofos gregos a se preocupar com a educação da infância. Contudo, sua análise educativa detinha apenas intencionalidades políticas. Nesse sentido, a infância não foi um objeto de estudo para Platão, porém, torna-se relevante, na medida "em que se tenha de educá-la de maneira específica para possibilitar que a pólis atual se aproxime o mais possível da idealizada” (KOHAN, 2003b, p. 14). Tratar de educação significava, então, produzir as melhores e mais aptas naturezas para governar a pólis com justiça. Qual era a estratégia para chegar à tal pólis? Ora, pois, a educação dos guardiões (crianças), daqueles que, mediante modelos apropriados, poderiam ser levados à excelência e à virtude na vida adulta; assim, nesse jogo político, seria possível a criação de uma pólis mais justa, melhor e bela. A visão platônica de infância está, portanto, fortemente ligada a uma etapa de vida - caracterizada pela falta, incompletude, inferioridade, ausência, incapacidade - que "adquire sentido em função de sua projeção no tempo" (KOHAN, 2004, p. 53). Podemos perceber a potência da ideia de infância projetada por Platão na Antiguidade clássica quando nos deparamos, no tempo presente, com traços muito marcantes de seu projeto.

Contudo, no decorrer da história, a infância ganhou outros contornos, outros espaços, outros discursos. O francês Philippe Ariès (1981) legou-nos um estudo sobre a História social da criança e da família, onde apresenta as diferentes conotações dadas à infância e as diferentes posições assumidas pela família ao longo da Idade Média. Nesse período, as crianças, com frequência, nasciam e morriam; quando apresentavam independência física, eram logo inseridas no mundo do adulto sem tratamento diferenciado - em festas, jogos, vocabulário, costumes, vestes; gozavam de uma função meramente utilitária para a sociedade, e a educação era de responsabilidade exclusivamente familiar. Significavam, nesse sentido, adultos em miniatura, sem particularidades específicas (ARIÈS, 1981).

O surgimento de um sentimento e/ou afeição para com a infância, até então inexistentes, ocorre somente na/com a Modernidade (KOHAN, 2004), o que nos leva a crer na existência de uma construção histórica e social sobre a noção de infância. Com a Modernidade, surgem um novo tempo, um novo espaço e uma nova criança (MALDONADO, 2017). A preocupação (do Estado, das Igrejas, da família) com a moralidade, a ética, a conduta, o comportamento das crianças, começa a aparecer. Como, porém, enquadrar a criança no 
modelo civilizatório de sociedade advindo com a Modernidade? Por meio da educação, das instituições educacionais modernas, "entre elas, aquelas encarregadas das crianças pequenas, desde a mais tenra idade” (BUJES, 2001, p. 35), que, mediante processos de disciplinarização, fabricam/produzem indivíduos. Foi nesse momento que a criança se tornou um objeto de relevância social, cultural e política, sobre o qual se tinha vontade de saber e de poder. Diferentes olhares têm se dedicado, a partir de então, a descrever, narrar, estudar, analisar a infância e a criança. "São estes olhares, com suas formas de representar as crianças, com práticas discursivas que esmeram em falar a verdade sobre elas, que parecem ser aqueles cujos efeitos são os mais disseminados e tomados como autorizados” (BUJES, 2001, p. 41, grifo da autora).

Assim, verdades vão sendo produzidas sobre as gentes pequenas, e as infâncias vão sendo narradas...

Inventaram verdades em que todos acreditavam, até mesmo as gentes novas que passaram a falar de si, a agir e a se pensar do mesmo modo, porque acabaram acreditando [...] fizeram assim para terem uma identidade e serem um sujeito com uma verdade. Mas também, o que elas poderiam ter feito se não isso? A não ser ficarem convictas de que seu verdadeiro Eu individual era aquele mesmo que estava [sendo discursado] (CORAZZA, 2002, p. 36).

O conjunto de ideias que acabamos de expor demonstra que a criança não pode narrar sua própria existência. É o adulto (e demais instituições normalizadoras) quem redimensiona, organiza suas narrativas, sua vida, sua história (LEAL, 2011). Nesse processo, fluem múltiplas possibilidades interpretativas de pensar a infância. Arriscamos dizer que o projeto educacional moderno não apenas capturou e institucionalizou o sujeito infantil, mas também o normalizou; produziu categorias lineares na forma de concebê-lo; compôs uma natureza infantil - caracterizada por ingenuidade, inocência, docilidade, fragilidade, dependência associada a uma etapa/fase de vida (a ser valorizada apenas na adultez).

Os conhecimentos organizados na forma de saberes científicos sobre a infância a têm situado claramente num continuum temporal da vida pontualmente delimitado, tecnicamente verificado e amplamente divulgado. A infância, nesse entendimento, circunscreve uma etapa do desenvolvimento biológico da vida humana compreendida entre 0 (zero) e 6 (seis) anos de idade ou, em termos mais amplos, entre o nascimento e a puberdade. Deste modo a infância integra os saberes constitutivos da ciência e demarca um campo de atividades onde estes saberes são aplicados. Há profissionais especializados em diferentes áreas do saber dedicados exclusivamente ao estudo da infância. Há também uma quantidade crescente de categorias profissionais direcionadas ao atendimento das necessidades infantis das mais diversas ordens, seja na forma de produtos comercializados, de serviços prestados à infância, ou mesmo de atendimento aos pais. Delimitada por sua característica temporal cronologicamente medida por meio de dias, semanas, meses e anos, a infância tem se tornado foco de inúmeras investigações (LEAL, 2011, p. 13). 
Vigiar seu crescimento. Estabelecer normas. Regular sua conduta. Controlar seu comportamento. Escolher seu vestuário e alimentação. Determinar horários. Impor regras e rotinas. Definir como deve ser. Dizer o que falar, como falar, quando falar. É isso que temos feito! Seria possível fazer (e pensar) diferente? Não sabemos. Porém, sentimo-nos provocadas a pensar a criança e a infância fora desse continuum, dessa linearidade histórica e temporal. Aprendemos com Deleuze (1992) a ver nas brechas, a olhar a intensidade existente nos fluxos. Queremos ver a infância com as lentes que não foram sugeridas para usarmos; propomo-nos pensá-la como um outro (LARROSA, 2000, p. 184), um enigma ainda não decifrado; pretendemos falar sobre ela a partir de autores que a vejam como experiência, acontecimento, devir e potência.

E o professor, aquele de quem falávamos no início deste subtítulo? Ah... Ele (assim como nós) também ocupa uma "posição estratégica na disseminação do poder disciplinar" (KOHAN, 2003, p. 88) na instituição escolar. Interessam a disciplina, a ordem, o silêncio. Mesmo sem saber, ele (o currículo e outras redes) governa e captura os corpos e mentes infantis (da mesma maneira, com a mesma forma). Como, porém, romper com esse pensamento estrutural dominante? Há como (des)capturar a criança e a sua infância?

\section{Uma infância movida por linhas de fuga e composições outras}

Diversas pesquisas e estudos trazem outros conceitos, outras formas e modos de pensar a infância. Em Pedagogia Profana: danças, piruetas e mascaradas (2000), Larrosa convidanos a pensá-la como "portadora de uma verdade à qual devemos nos colocar à disposição de escutar” (LARROSA, 2000, p. 186). Mas isso não quer dizer, necessariamente, que exista uma verdade sobre o que ela seja de fato. A infância é aquilo que ainda não sabemos, é o enigma (falado há pouco) que inquieta a segurança de nossos saberes/práticas e escapa a qualquer processo de objetivação. É o outro que não pode ser abarcado e/ou submetido.

Em um texto que descreve a infância como novidade para o mundo, Larrosa cita Hannah Arendt - filósofa alemã - para dizer que o nascimento de uma criança é algo que suspende a certeza que temos de nós próprios. Quando uma criança nasce, existe a possibilidade de renovação do mundo, porque a criança traz o novo, o desconhecido, aquilo que não foi capturado pelos nossos discursos e saberes. Infância, entendida como o que nasce, suspende a cronologia e as verdades já proferidas. No entanto, o mundo e os indivíduos (adultos e detentores de verdades) apresentam um mundo velho para a criança que nasce. Mesmos saberes e práticas. Mesmas projeções futuras. Mesmos desejos. Mesmas utopias. Seria possível constituir um olhar capaz de acolher o acontecimento daquele que nasce? (LARROSA, 2000). Se deixarmo-nos atravessar pela experiência da infância e transformarmos aquilo que pensamos e acreditamos saber, quiçá, sejamos capazes de outro saber e de outras práticas (não aquelas institucionalizadas).

Talvez seja Kohan (2003) quem nos possibilite melhor compreender esse encontro com a infância. Em seu livro Infância: entre educação e filosofia, Kohan conceitua a infância 
como um símbolo da afirmação, figura do novo, espaço de liberdade; como imagem de ruptura, de descontinuidade, de quebra do normal e do estabelecido (KOHAN, 2003). Aqui, a infância é o agora (não o amanhã, o futuro), é o corpo (não capturado e significado), é a intensidade de uma vida (não cronológica, sucessiva e linear).

O encontro com a infância ocupa um espaço que se passa entre; habita o espaço do devir (do roubo, do achado, da captura, que difere do plágio, da cópia, da imitação) (KOHAN, 2003). O encontro com a infância precisa estar aberto ao enigma do início (e do fim?), embora pensá-la abra portas ao impensável e ao inesperado (sem continuidade temporal). Certamente, reportar-se à infância exige uma tarefa de quebra. Sobretudo, a quebra do eu (individual), transpassando as redes que para nós foram engendradas. Isso, por si só, justifica os seus escapes.

A infância responde com uma linha de fuga a tudo aquilo que tenta aprisioná-la. Será? Vejamos!

Dia 22 de maio de 2019, quarta-feira, aula de Matemática. Silêncio! Alunos enfileirados. Explicação do professor sobre divisão de fração. Todos estavam atentos à sua fala. Pergunta básica no ar: "Todos entenderam?” $O$ "sim”, como sempre, as crianças responderam. Então... Mãos à obra: atividades de fixação de conteúdo na lousa! Nesse intervalo de tempo, o professor, o conteúdo passava, $e$ as crianças, no caderno, copiavam. Lá no fundo da sala, passando quase despercebida, a caixinha do desabafo estava. Pouco tempo depois, o professor, à mesa do fundo da sala, se sentou. Com quem? Com aqueles que a atividade erraram. Os demais já haviam terminado a atividade. Sim! Rápidos, não? Com o "dever" cumprido, mesas se juntaram, e eles com slime brincaram. Todos? Não. Alguns pegaram tesouras, cola e papel e fizeram barquinhos sob o comando do tenente-coronel (Anotações cartográficas - escapes do cotidiano).

Está tudo aí! Percebam os escapes, as linhas de fuga que os próprios alunos encontram para burlar as regras (normas e demais ordens disciplinares) da sala de aula. Ora, o cumprimento das atividades (de rotina) significa que estão "livres" (embora saibamos que não) para viver o tempo de aión (tempo da intensidade, do devir, de uma vida), fazendo o que querem e gostam. Nesse cotidiano, eles se fazem e (re)fazem de forma singular, tornando seu esse espaçotempo. Brincar de slime ou de barquinho de papel é a fuga da realidade; é encontrar novos meios para deixar fruir a imaginação e os sentidos. Brincar é também construir uma identidade, construir o mundo, aprendendo e brincando com os significados e práticas de seus mundos sociais (ABRAMOWICZ, 2017). Esse episódio mostra que a infância se encontra em um devir, em um detalhe. É um horizonte (ao mesmo tempo intocável e inestimável), mas carece ser sentida e vivida.

Por isso, de acordo com Abramowicz (2017, p. 25), temos que nos "opor às prescrições que estão nas bases de currículos unificados”. A infância não pode continuar sendo produzida pelo adulto e seus discursos. É preciso, pois, cartografá-la, desemaranhar as linhas molares pelas quais foi composta, percorrendo suas linhas de fuga e de rupturas. Por onde começar? 
Na escola, talvez. Nesse lugar de passagem (KOHAN, 2010) que o tempo suspende e onde se demora.

Pensando nessa conversa, com um olhar que abre aos acontecimentos, vimo-nos, mais uma vez, presas a outra cena que capturou nossos sentidos no cotidiano escolar... Em uma terça-feira, no final da aula de Português, fomos convidadas pelos alunos e pelo professor para assistir à aula de Artes, a ser realizada na sala de multimeios. Os alunos estavam eufóricos! Para eles, seria uma aula cheia de expectativas e encontros. Pensamos que a espera pelo novo contagiou aqueles que buscavam vivenciá-lo. Ficamos muito animadas e, sem pensar duas vezes, aceitamos! Lá do fundo, ouvíamos risos. Parece que nossa presença ali também fazia parte do quadro de expectativas. Foi quase inevitável não desenvolver também aquele anseio, aquele sentimento de que algo poderia acontecer ali. Assim... Na sala dos professores, ficamos aguardando a tão esperada aula. O momento chegou! Com o caderno de campo e demais artefatos em mãos, seguimos em busca de experiências singulares, de acontecimentos imprevistos, do encontro com o outro. Pensamos que pesquisar seja isso, ir ao encontro do desejo. De um desfazer-se e refazer-se. De um abrir-se ao encontro com o novo. De um ir ao encontro do outro de nós.

Com esse pensamento, carregando um turbilhão de sensações, pedimos licença e adentramos na sala de multimeios. Enquanto tentávamos passar despercebidas e não atrapalhar a aula do professor, fomos convidadas, pelos alunos, a sentar em um lugar que prepararam especialmente para nós. Ficamos contentes com tamanha gentileza. Sentamonos! Pegamos o caderno de campo e procuramos anotar os detalhes que, muitas vezes, passam imperceptíveis aos olhos do professor. Estava tudo escuro - um ar de friozinho na barriga predominava naquele lugar. Os alunos sentavam-se em cadeiras que giravam - a toda hora, viam-se alunos girando para lá e para cá. O professor, à frente, sentava-se. Com um notebook com acesso à internet conectado à televisão, o YouTube carregava um vídeo sobre as “danças típicas da região Centro-Oeste do Brasil” - conteúdo este indispensável na disciplina de Artes, de acordo com a Base Nacional Comum Curricular (BNCC) ${ }^{7}$.

Catira. Cururu. Danças indígenas mato-grossenses. Sarandi. Siriri. Dança de São Gonçalo. Essas foram algumas das danças apresentadas aos alunos. Conforme as danças eram exibidas, o professor pausava o vídeo para destacar informações relevantes sobre origem, ritmos, artefatos, vestes e espaçotempo - menções também eram feitas à disciplina de História, pois se tratava de um conteúdo relacionado à cultura dos povos; à disciplina de Geografia, tendo em vista que as danças eram oriundas de uma região do Brasil de forma especial (Centro- Oeste); e à disciplina de Ensino Religioso, uma vez que misticismo, símbolos e artefatos carregam um valor simbólico distinto em cada dança. Nesse sentido, estava evidente o caráter interdisciplinar daquela aula.

Essa é uma experiência que permite fazermos de nossos currículos “novos mapas, não mais marcados por territórios fragmentados, mas tentando ultrapassar fronteiras, vislumbrar novos territórios de integração entre os saberes. Um dos caminhos possíveis é o da interdisciplinaridade” (ALVES; GARCIA, 2000, p. 25). Olha a pluralidade de significações e representações tecidas em uma aula como essa! Quantos signos, possíveis conexões, 
devires e trajetos foram agenciados ali? O professor, com sua prática molecular, agenciou experiências que podem carregar novas possibilidades de ser e agir dentro da escola.

Experiências como essas nos fazem tecer relações sobre a protagonista do processo de aprendizagem: a criança - esse sujeito (do passado, do presente e do futuro) que entoa simulacros, ouve contos e se torna contos (KOHAN, 2010), vive seu tempo demasiadamente devagar, alça voo e cria suas próprias direções.

Questionamos: o que pode uma criança? Não sabemos. Mas problematizá-la talvez possibilite o encontro com devires minoritários que não imitam ou modelam, ou seja, não buscam normatizar o tipo ideal ao qual uma criança deva conformar-se, mas interromper o que já está instituído; desencadeando intensidades disruptoras, propiciam novos inícios (KOHAN, 2004). A partir daqui, afirmamos: criança é vida imanente, criança é pura potência! E a infância? Ah... Esse é um labirinto que não nos atrevemos a desvendar...

De modo geral, neste artigo, vimos que o currículo instituído (a todo momento, presente em nossas narrativas a partir da descrição das ações dos professores) funciona na fabricação do corpo infantil. Evidencia-se como os artefatos culturais são dispositivos fundamentais e como movimentam o currículo, contribuindo para a constituição do corpo infantil - o sino, as filas, as cartolinas, os jogos, o pingue-pongue, as pesquisas, as regras da sala, o silêncio, a atenção, as carteiras enfileiradas ou em círculo, o quadro enchendo-se e esvaziando-se de exercícios de fixação, os cadernos, as canetas, os lápis, as borrachas, a sala de multimeios, o computador, o Datashow, as cadeiras giratórias - tudo isso funciona na fabricação do corpo infantil. Porém, como vimos, a criança é vida imanente, é potência! Com sua força, rompe, cria outras linhas a partir das linhas a ela disponibilizadas e constitui-se singularmente. O currículo não tem como escapar das linhas molares, moleculares e de fuga que perpassam o cotidiano escolar.

\section{Notas}

1. Este texto é resultado de uma pesquisa desenvolvida em uma dissertação de mestrado que trata sobre os usos dos artefatos culturais e tecnológicos no espaçotempo da escola. Nesse contexto, para estar entre as infâncias e as crianças e problematizar os usos que fazem dos artefatos culturais e tecnológicos em sala de aula, adotamos a postura de pesquisadoras e deixamo-nos habitar pelos fluxos de uma unidade escolar situada no município de Mirassol D’ Oeste escola pública estadual, recente e tradicional, localizada na mesorregião sudoeste do estado de Mato Grosso. Nessa escola, abrimo-nos aos encontros com oito professoras/es que lecionam nos anos iniciais do ensino fundamental e 27 alunas/os que compõem a turma do $5^{\circ}$ ano do ensino fundamental nessa instituição no período matutino. A partir da observação dessa turma de alunas/os e da entrevista com as/os professoras/es, foi possível problematizar os artefatos culturais e tecnológicos, compondo novas maneiras de ver e escutar o currículo e as infâncias.

2. Optamos pela junção de algumas palavras, bem como grafá-las em itálico - tais como os termos encontrospotentes, espaçotempo, praticantespensantes -, inspiradas nas pesquisas nos/dos/com os cotidianos. Essa opção política tem como objetivo indicar que, embora o modo dicotomizado de criar conhecimentos na sociedade moderna seja, ainda hoje, hegemônico, tem significado limites ao desenvolvimento das pesquisas. Nesse sentido, Alves aponta: “essa foi a melhor forma que encontrei, depois de usar outras, para dizer da unidade indissociável de seus dois componentes, que na verdade precisam ser entendidos como um só, na tentativa de superar a visão dicotomizada que herdamos da modernidade" (ALVES, 2000b, s/p).

3. Optamos por utilizar um nome fictício para referirmo-nos à escola pesquisada.

4. Utilizamos nomes fictícios para resguardar a identidade dos professores pesquisados. 
5. Concordamos com o pensamento de Leal (2011, p. 45) quando diz que "ensinar parece ser preponderante em relação a aprender. Aprender é uma consequência do ensinar. Do ensinar deriva-se o aprender. Pareceria absurdo propor uma nova ordem? Aprendizagem-ensino?”.

6. Inclusive, o pensamento e as ideias de Platão tiveram forte influência nas correntes pedagógicas do pensamento ocidental moderno - aquelas que, de certa forma, também acabaram produzindo um tipo determinado de sujeito infantil.

7. Tecemos, em outro momento de nossa pesquisa, a necessária discussão, nos tempos atuais, sobre os desafios de se pensar o trabalho pedagógico no Brasil a partir da aprovação da Base Nacional Comum Curricular (BNCC), no ano de 2017. Sobre essa temática, sugerimos aos leitores o artigo "Fazendo a Base virar realidade: competências e o germe da comparação” (MACEDO, 2019).

\section{Referências}

ABRAMOWICZ, Anete. Infância e pós-estruturalismo. São Paulo: Porto de Ideias, 2017.

ABRAMOWICZ, Anete. Sociologia da Infância: traçando algumas linhas. Contemporânea, v. 8, n.2. p. 371383. 2018.

ALVES, Nilda; GARCIA, Regina Leite. A invenção da Escola a cada dia. Rio de Janeiro: PD\&A, 2000.

ALVES, Nilda; GARCIA, Regina Leite. O sentido da escola. - 2. ed. - Rio de Janeiro: DP\&A, 2000 b.

ARIÉS, Philippe. História Social da Criança e da Família. 2. ed. Tradução de Dora Flaksman. Rio de Janeiro: LTC Editora, 1981.

BUJES, Maria Isabel Edelweiss. Infâncias e maquinarias. - Rio de Janeiro: DP\&A, 2001.

CANDAU, Vera Maria. Reinventar a escola. - 6. ed. - Petrópolis, RJ: Vozes, 2008.

CORAZZA, Sandra Mara. Contribuições de Deleuze e Guattari para as pesquisas em educação. Revista Digital do Laboratório de Artes Visuais, n. 8, 2012.

CORAZZA, Sandra. Era uma vez... Quer que conte outra vez?: As gentes pequenas e o indivíduo. In: GARCIA, Regina Leite (Org.). Crianças, essas conhecidas tão desconhecidas. Rio de Janeiro: DP\&A, 2002.

DELEUZE, Gilles. ¿Que és un dispositivo? Tradução de Wanderson Flor do Nascimento. In: Michel Foucault, filósofo. Barcelona: Gedisa, 1990.

DELEUZE, Gilles. Conversações. Tradução de Peter Pál Pelbart. - Rio de Janeiro: Ed. 34, 1992.

DELEUZE, Gilles; GUATTARI, Félix. Mil platôs: capitalismo e esquizofrenia. Tradução de Aurélio Guerra Neto e Celia Pinto Costa. - São Paulo: Ed. 34, 1995.

FOUCAULT, Michel. Microfísica do poder. Organização e tradução de Roberto Machado. Rio de Janeiro: Edições Graal, 1979.

GALLO, Sílvio. Em torno de uma educação menor. Educação e Realidade, v. 27, n. 2, 2002.

GUATTARI, Félix; ROLNIK, Suely. Micropolítica: cartografias do desejo. - 4. ed. - Petrópolis, RJ: Editora Vozes, 1996.

KOHAN, Walter Omar. Devir-criança da filosofia: Infância da educação. - Belo Horizonte: Autêntica Editora, 2010.

KOHAN, Walter Omar. Infância e educação em Platão. Educ. Pesqui. v.29 n.1, 2003b.

KOHAN, Walter Omar. Infância: entre educação e filosofia. Belo Horizonte: Autêntica, 2003.

KOHAN, Walter Omar. O mestre inventor: relatos de um viajante educador. - Belo Horizonte: Autêntica Editora, 2015.

KOHAN, Walter. Omar. A infância da educação: o conceito devir-criança. In: Walter Omar Kohan. (Org.). Lugares da Infância: filosofia. - 1ed. - Rio de Janeiro: DPA, 2004.

LARROSA, Jorge. Elogio da escola. - 1. ed. - Belo Horizonte: Autêntica Editora, 2017. 
LARROSA, Jorge. Esperando não se sabe o quê: sobre o ofício de professor. - 1. ed - Belo Horizonte: Autêntica Editora, 2018.

LARROSA, Jorge. Pedagogia Profana: danças, piruetas e mascaradas. 3. ed. Belo Horizonte: Autêntica, 2000. LEAL, Bernadina Maria de Sousa. Chegar à infância. Niterói: EdUFF, 2011.

MACEDO, Elizabeth Fernandes de. Fazendo a Base virar realidade: competências e o germe da comparação. Revista Retratos da Escola, Brasília, v. 13, n. 25, p. 39-58, jan./mai. 2019.

MALDONADO, Maritza Maciel Castrillon. Espaço pantaneiro: cenário de subjetivação da criança ribeirinha. - Curitiba: CRV, 2017.

MASSCHELEIN, Jan; SIMONS, Maarten. Em defesa da escola: uma questão pública. Tradução de Cristina Antunes. -2. ed. - Belo Horizonte: Autêntica Editora, 2018.

OLIVEIRA, Inês Barbosa de. Práticas cotidianas e emancipação social: do invisível ao possível. Petrópolis, RJ: DP et Alii, 2010.

ROLNIK, Suely. Cartografia sentimental: transformações contemporâneas do desejo. - 2. ed. - Porto Alegre: Sulina, 2016.

SILVA, Tomaz Tadeu da. Documentos de identidade: uma introdução às teorias do currículo. - 2. ed. - Belo Horizonte: Autêntica, 2007.

SILVA, Tomaz Tadeu da. Liberdades reguladas: a pedagogia construtivista e outras formas do governo do eu. - Petrópolis, RJ: Vozes, 1998.

SILVA, Tomaz Tadeu da. O currículo como fetiche: a poética e a política do texto curricular. Belo Horizonte: Autêntica, 2001.

VEIGA-NETO, Alfredo José da. Crítica pós-estruturalista e educação. Porto Alegre: Sulina, 1995.

\section{Correspondência}

Luana dos Santos Nogueira Garcia: Graduada em Pedagogia (2017) pela Universidade do Estado de Mato Grosso (UNEMAT); Mestranda no Programa de Pós-Graduação em educação - PPGEdu/UNEMAT. Professora da Educação Básica da rede estadual de Mato Grosso.

E-mail: luaninhanogueira84@gmail.com

Maritza Maciel Castrillon Maldonado: Doutora em Educação pela Universidade Federal Fluminense. Concluiu estágio sanduíche na Universidade Complutense de Madrid, Espanha. Professora da Universidade do Estado de Mato Grosso - UNEMAT, atuando no Programa de Pós-Graduação em Educação e no curso de Pedagogia.

E-mail: maritzacmaldonado@gmail.com

Texto publicado em Currículo sem Fronteiras com autorização das autoras 